NBER WORKING PAPER SERIES

REFLECTIONS ON ONE YEAR AT THE BANK OF ISRAEL

\author{
Stanley Fischer \\ Working Paper 12426 \\ http://www.nber.org/papers/w12426
}

NATIONAL BUREAU OF ECONOMIC RESEARCH
1050 Massachusetts Avenue
Cambridge, MA 02138
August 2006

Governor, Bank of Israel. Earlier versions of this paper were presented at the Conference of Governors of Central Asia, the Black Sea, and the Balkans, hosted and organized by the Central Bank of Russia, in Kazan, Russia, May 2006; at the annual meeting of the Israeli Economic Association on May 30, 2006; and at the NBER in Cambridge, Mass on July 10, 2006. I am grateful to Karnit Flug for her comments, and to colleagues in the Research and Monetary Departments of the Bank of Israel, and to Gaby Fishman, for essential assistance. I am grateful also to Julio Rotemberg of the Harvard Business School for a helpful discussion. As this paper reflects on the period through the end of April 2006, I have not attempted to relate to changes in the security situation that occurred in July 2006. The views expressed herein are those of the author(s) and do not necessarily reflect the views of the National Bureau of Economic Research.

(C2006 by Stanley Fischer. All rights reserved. Short sections of text, not to exceed two paragraphs, may be quoted without explicit permission provided that full credit, including (C) notice, is given to the source. 
Reflections on One Year at the Bank of Israel

Stanley Fischer

NBER Working Paper No. 12426

August 2006

JEL No. E50, E65

\begin{abstract}
$\underline{\text { ABSTRACT }}$
In this paper I reflect on my first year as Governor of the Bank of Israel, which I joined in May 2005. I start by describing the current state of the Israeli economy and monetary policy and economic developments during the past year. I then review a series of issues that have arisen during the past year. Among them are: the monetary mechanism, which is unusual because exchange rate changes have a very rapid impact on prices; the role of inflation and interest rate expectations in policy decisions; the role of the interest rate gap with the US; the role of the Governor as chief economic adviser to the Government; banking supervision; and management and political issues.
\end{abstract}

Stanley Fischer

Bank of Israel

PO Box 780

Jerusalem, 91007

ISRAEL

and NBER

sfischer@bankisrael.gov.il 


\title{
Reflections on One Year at the Bank of Israel
}

\author{
Stanley Fischer
}

I began serving as Governor of the Bank of Israel on May 1 2005, and it might be useful

- certainly for me - to reflect on some of the lessons learned and issues my colleagues and I have grappled with during my first year on the job. I will start by reviewing the state of the Israeli economy in recent years, and then move on to discuss the monetary policy decisions that were made during the last twelve months and some of the issues that have arisen during that time.

\section{The Israeli Economy}

Per capita GDP in Israel is about $\$ 18,500$, around $\$ 22,500$ in purchasing power parity terms. The population has recently crossed the 7 million mark. Total GDP is about $\$ 130$ billion. ${ }^{1}$ The government spends around 50 percent of GDP, but that share has been declining in recent years. ${ }^{2}$ The share of taxes in GDP is only slightly above the OECD average and income tax rates - corporate and personal - are programmed to decline by one percentage point per year through 2010. ${ }^{3}$ Inflation is low. The current account of the balance of payments has been in small surplus recently.

\footnotetext{
* Governor, Bank of Israel. Earlier versions of this paper were presented at the Conference of Governors of Central Asia, the Black Sea, and the Balkans, hosted and organized by the Central Bank of Russia, in Kazan, Russia, May 2006; at the annual meeting of the Israeli Economic Association on May 30, 2006; and at the NBER in Cambridge, Mass on July 10, 2006. I am grateful to Karnit Flug for her comments, and to colleagues in the Research and Monetary Departments of the Bank of Israel, and to Gaby Fishman, for essential assistance. I am grateful also to Julio Rotemberg of the Harvard Business School for a helpful discussion. As this paper reflects on the period through the end of April 2006, I have not attempted to relate to changes in the security situation that occurred in July 2006.

${ }^{1}$ A change in the methodology for computing GDP in July 2006 led to an increase in estimated GDP of nearly five percent.

${ }^{2}$ From 2003 to 2006, the government was operating under a self-imposed constraint that real government spending should not rise by more than 1 percent a year. Under the new government that has taken office recently, that constraint will be raised to 1.7 percent a year, the rate of population growth.

${ }^{3}$ The Bank of Israel Annual Report for 2005, available in English in hard copy and on the Bank of Israel website (www.bankisrael.gov.il), contains comprehensive information on the Israeli economy, including comparative international data on fiscal variables.
} 
The Israeli economy has performed very well in the last few years. Following a deep recession in 2001-2003, the global recovery, and a rigorous fiscal and structural reform program introduced by the Sharon government in 2003, for which then Finance Minister Netanyahu was primarily responsible, the economy began to grow in the second half of 2003. Growth accelerated subsequently (Figure 1), reaching a rate of 5.2 percent in 2005. The most recent data for the first quarter of 2006 show quarterly growth at an annual rate of 6 percent, with business sector growth of 7.5 percent at an annual rate.

Israel has an inflation target range, set by the government, of 1-3 percent. ${ }^{4}$ The inflation rate has fluctuated around that range since the start of this decade. As Figure 2 shows, the target was undershot in 2003 and 2004, and was achieved in 2005. The inflation rate for the last twelve months (April 2006/April 2005) lies above the range, but expectations are that inflation for the calendar year 2006 will be within the range and that inflation for the next twelve months will be close to the center of the target range of 2 percent. Breakeven inflation rates, derived from the term structures of interest for nominal and indexed bonds, rise gradually, ending for a 10-year horizon at 2.8 percent; Bank economists estimate that this implies a ten-year expected inflation rate of 2.3 percent. $^{5}$

The exchange rate of the shekel floats freely, and there has been no central bank intervention in the foreign exchange market since 1997, when the exchange rate band was effectively ended. Capital controls were removed gradually, ${ }^{6}$ with the final step being taken in 2003 when Israeli financial institutions, including pension and mutual funds, were permitted to invest freely abroad. The exchange rate of the shekel has maintained an impressive degree of stability (Figure 3), in part I believe because it is clearly

\footnotetext{
4 Monthly inflation in Israel is more variable than that in the major economies; seasonal adjustments are not very reliable; and the ability to forecast inflation rates beyond a year is poor relative to that in countries with a longer history of price stability.

${ }^{5}$ There is a risk premium in the break-even inflation rate that is estimated to be about 0.5 percent at the 10 year horizon.

${ }^{6}$ See Stanley Fischer, "Capital Account Liberalization: the Israeli Experience", Bank of Israel, January 2006.
} 
understood that the Bank of Israel will not intervene in the foreign exchange markets except in the most exceptional of circumstances.

The Israeli economy is very open, with imports amounting to over 40 percent of GDP and exports to close on 38 percent (Figure 4). There has been a surplus in the current account of the balance of payments in the last few years, which amounted to three percent of GDP in 2005. Large capital inflows, both portfolio and direct investment, approximately 9 percent of GDP in 2005 (Figure5), have been essentially matched by outflows of Israeli capital as domestic residents, corporations, and institutional investors, diversify their portfolios. There has thus been no serious appreciation pressure on the shekel from the large gross capital inflows of recent years; indeed, since 2001 there has been a 30 percent devaluation of the real effective exchange rate of the shekel, though only a 10 percent real devaluation against the dollar. ${ }^{7}$

Following the reform program of 2003, government finances have strengthened (Figure 6). The fiscal deficit in 2005, targeted at 3 percent of GDP, ended the year just below 2 percent. ${ }^{8}$ Because of the elections, the budget for 2006 is only now being passed through the Knesset. In the interim the budget was managed under the terms of a law that specifies that in the absence of an approved budget, one-twelfth of the previous year's budget is to be executed each month. Given strong growth, real tax revenues have grown significantly, and it is likely that the budget for the first half of the year will be balanced or slightly in surplus. The Finance Minister has committed to not permitting the actual budget deficit for 2006 to exceed one percent of GDP. The most serious weakness in the fiscal picture is the high level of government debt, which currently stands at around 95 percent of GDP. That ratio has been declining in recent years, and under current budget plans - including the fact that privatization revenues are counted below the line - and

\footnotetext{
${ }^{7}$ Despite the fact that Israel trades more with Europe than the United States, public discussion of the exchange rate focuses on the exchange rate with the dollar, which is also the unit of account in many contracts, and which is dominant in the capital account.

${ }^{8}$ The standard definition of the budget deficit used in public discussion in Israel refers to the budget of the central government, and does not include the accrual of payments due on indexed bonds. By international definitions, the budget deficit of the general government in 2005 was 4 percent of GDP, including indexation payments that accrued during the year. For details see the Bank of Israel Annual Report for 2005, Table 6-4, p.236.
} 
reasonable growth performance, will continue to decline. It is important that the ratio should decline.

The unemployment rate peaked at 11 percent in 2003, and has been declining gradually since, with the most recent estimate, for February, being 8.7 percent (Figure 7). As in many countries, unemployment rates in Israel are on average higher for those with less formal education; recent growth has begun to reduce unemployment rates for all educational groups. ${ }^{9}$ Labor force participation rates in Israel are low, in part as a result of the low participation rates on the part of ultra-religious men and of Arab women.

Despite the rapid growth of the economy since 2003, poverty rates have continued to rise Figure 8). The standard measure of poverty in Israel is a relative one, with the poverty line being defined as half the median income (adjusted for family size). But poverty has risen even when defined in absolute terms. ${ }^{10}$ Through 2003, the increase could be attributed mainly to the effects of the recession. However the increase in poverty in 2004 and in the first half of 2005 (the latest period for which data are available) was in significant measure due to cuts in welfare allowances that were introduced during the 2003 reform program, partly to encourage greater labor force participation. Poverty rates are especially high for the ultra-religious and Arab sectors of the population, which together account for less than 30 percent of the population but over half the poor. Social issues, particularly the rise in poverty, were high on the agenda in the recent election, and are likely to receive attention from the new government.

The prospects for the continuation of rapid growth depend on three main factors: on the performance of the global economy, into which Israel is well and increasingly integrated; on domestic policies - the maintenance of a strong fiscal framework and continuation of the reform process; and on Israel's geopolitical situation.

\footnotetext{
${ }^{9}$ See the Bank of Israel Annual Report for 2005.

${ }^{10}$ The Annual Report for 2005 includes a chapter on poverty issues, including alternative measures of poverty.
} 


\section{Monetary Policy since May 2005.}

Under the current law, the Governor makes the interest rate decision. Discussions on the decision take place monthly in a small committee that includes the heads of the four relevant departments (Research, Monetary, Foreign Exchange, and Foreign Exchange Activities ${ }^{11}$ ), some advisors, and the Governor. The meeting of the small committee is preceded by a wider meeting with staff in which representatives of the four departments make presentations on the state of the domestic and international economies designed to inform the interest rate decision. No policy recommendations are made in the wider forum.

The Governor receives a written recommendation from each of the four department heads before the meeting of the small committee. In the past twelve meetings the recommendations have more often than not, but not always, been unanimous. There is then a discussion during which the decision is made. The department heads make their final recommendations (they are not bound by their previously written recommendations) and the Governor makes the decision. A draft, or alternative drafts, of the announcement is generally prepared beforehand and may be discussed before the decision is made. The announcement is then refined after the decision has been made.

Figures 2 and 9 show interest and inflation rates in Israel in the period since January 2005. The policy interest rate in May 2005 was the lowest in Israeli history, and the inflation rate had recently been below its target range. At this stage the Fed was well into its process of rising rates by 25 basis points at each meeting, so that the gap between the Israeli policy rate and that of the Fed was continually declining, until in September 2005 the gap became negative for a short while.

\footnotetext{
${ }^{11}$ The Foreign Exchange department manages the reserves and would undertake any intervention in the foreign exchange market if that were to happen; the Foreign Exchange Activities department was previously in charge of foreign exchange controls, and currently collects comprehensive data on foreign exchange transactions. The present arrangement of the departments is likely to change in a reorganization currently under way.
} 
During the course of the summer the Bank maintained its interest rate at 3.5 percent, but the announcement of the decision not to raise the rate for September noted the Bank's concerns about rising inflation. At the end of September 2005, the interest rate for October was raised from 3.5 to 3.75 percent. In its statement of the reasons for raising the rate, the Bank noted particularly the increasing signs of upward pressure on prices, and the fact that the short-term interest rate gap with the United States was negative.

Against the background of continuing rapid growth and estimates that the output gap was closing quite rapidly, with rising concerns about inflation, resulting in part from a depreciation of the shekel, and the Fed's continued increases in its rate, the Bank of Israel raised its interest rate by 25 basis points for November and by 50 basis points, to 4.5 percent by the end of the year. By that stage it was clear that inflation was running at a higher rate than it had been a year before, and that it was likely that the inflation rate for the past twelve months would rise above 3 percent in the first quarter of 2006.

With growth continuing and the output gap shrinking, and against the background of higher inflation, the Bank has subsequently raised the rate three times, to a level currently of 5.25 percent.

\section{Monetary Policy Issues}

The Bank of Israel pursues a flexible approach to the inflation targeting regime, that is to say, in considering how to respond to shocks that might move the inflation rate outside the target range, it weighs how rapidly it should try to get back within the range recognizing that being too ambitious in attaining the inflation target rapidly might produce unacceptable output costs. There is however no flexibility in the fact that the Bank's intention is to return to within the target range.

This is consistent with the goals of monetary policy as laid out in the new law of the Bank of Israel, which the government is committed to introducing: ${ }^{12}$

\footnotetext{
12 This is an unofficial translation from the Hebrew.
} 
"(1) To maintain price stability over the course of time; this is the central goal;

(2) To support the other goals of government economic policy, especially growth and employment, on condition that that doing so will not impede the attainment of the goals specified under (1) above and (3) below;

(3) To support the efficient operation of the financial system, and its stability."

The law also stipulates that the inflation target will be specified by the government.

Several issues arise in implementing this approach:

\section{Data.}

The data on which monetary policy decisions are based are of variable quality relative to those available in other countries. Data on expectations of inflation and other financial variables are of high quality and frequency. As in many countries, data on the level of economic activity are relatively poor.

- The CPI and wholesale price index for each month are published in the middle of the following month.

- Information about expectations is available very rapidly. Asset prices are of course available daily, and various expectational measures can be derived from those prices. Thus for instance the daily information sheets that circulate in the Bank contain daily expected inflation measures, derived from the term structures of interest for real and nominal bonds. ${ }^{13}$ Expected inflation measures are also published daily in the newspapers. Market analysts publish regular reports, providing another source of information about expectations. Measures of inflation expectations (and expectations about other economic variables) of firms are available from the quarterly survey of companies.

\footnotetext{
${ }^{13}$ They also include information about the standard deviation of expectations of the exchange rate, based on the prices of foreign exchange options. At the monetary policy decision meetings, and at weekly update meetings, we also have available derived information about the distribution of expectations of inflation rates.
} 
- Information about real activity is available only with a much longer lag. The fundamental source is the national income accounts, which are published quarterly, on average about 6 weeks after the end of the previous quarter. This means that on average this information is 4.5 months out of date. ${ }^{14}$ In addition, the data are often revised, sometimes quite significantly. Qualitative information about output and output expectations is available quarterly from a survey of large companies, which comes in two weeks after the end of the quarter.

Unemployment data are published only quarterly, though some information which the Central Bureau of Statistics does not regard as very reliable - is available about monthly unemployment rates, with a 2-month lag. The basic problem here is the small size of the sample. A concurrent index of economic activity is published by the Bank monthly, as is a related private sector-published index. The Bank regards the indicator series as informative. There are also other sources of monthly information, including credit card purchases, industrial production, imports and exports, and government tax receipts.

In brief, expectations about inflation are available almost instantly, price information is available with a relatively short lag, but information about real activity is both available only with a much longer lag, and is less reliable. The lags in obtaining information about real activity could have a serious effect on the speed and effectiveness with which monetary policy would react to any significant cyclical turning point in real activity.

\section{The monetary mechanism.}

Changes in interest rates operate through several channels: the exchange rate; the standard textbook channels; and expectations.

\footnotetext{
14 The calculation is: on average the information about quarterly GDP can be attributed to the middle of the previous quarter (a 6-week lag); that information is first published 6 weeks after the end of the quarter (another 6 weeks); and on average the published information is 6 weeks old (another 6 weeks).
} 
- As in most economies, a change in the interest rate has an almost immediate impact on the exchange rate. ${ }^{15}$ That is standard. Less standard is the fact that in Israel the exchange rate then has a rapid and significant impact on prices of some non-traded goods. For historical reasons, a result of the hyperinflation, some prices - prominent among them prices of non-traded goods - are specified in dollars. Thus rental contracts for real estate, payments for housing under construction, lawyers' and accountants' fees, and even prices for catering, usually specify prices in dollars - though payment will be in shekels. ${ }^{16}$ This channel operates in addition to the normal links between imported and domestic prices, which typically have a longer lag. ${ }^{17}$

- This tight link between some prices and the exchange rate both complicates and simplifies the task of monetary policy. It complicates the task of monetary policy because any disturbance that affects the exchange rate with the dollar - for instance a weakening of the dollar in the world, or a change in expectations about the Israeli economy - almost immediately affects inflation, and may require a response from monetary policy to ensure that the inflation target is attained. In this regard, it would be more convenient if the strong and immediate exchange rate-inflation link were absent.

- The tight link also simplifies the task of monetary policy, because monetary policy can have a rapid impact on prices if it can affect the exchange rate. Of course, use of the exchange rate channel typically also implies a (possibly temporary) change in the real exchange rate, so that the implications of the exchange rate channel have always to be carefully considered. In addition, monetary policy needs to contend with the lagged impact of earlier policy changes on inflation, which could produce instrument instability.

\footnotetext{
${ }^{15}$ I omit here subtleties about when the change in the interest rate was first expected.

${ }^{16}$ The contracts typically specify that the payment in shekels will use the representative exchange rate for that day published by the Bank of Israel. One recommendation we have received in discussions about how to reduce the strength of the link between the exchange rate and prices is to stop publishing the representative rate.

${ }^{17}$ In the case of gasoline, prices are controlled but adjust very rapidly to imported prices: they are adjusted for each month based on international prices for the last five days of the previous month.
} 
- In addition, changes in monetary policy affect inflation through the standard textbook channels: induced changes in the exchange rate affect the prices of imports, which then feed through into domestic prices; and the interest rate channel affects aggregate demand, ${ }^{18}$ and thus the output gap and price and wage behavior. The lags here are likely to be longer than those that operate through the use of the dollar as unit of account.

- The expectations channel is particularly important. For nearly three years, inflation expectations have been quite stable, fluctuating around the center of the target range, 2 percent. This reflects expectations of market participants about the commitment and ability of the central bank to attain the inflation target on average over long periods. It almost surely means that the expectations channel in the expectational Phillips curve is less affected by short-term movements in inflation than it would be absent the inflation targeting approach, and thus induces an important element of stability in wage and other price-setting behavior.

How do these channels interact? Dynamic multipliers for a 100 basis point increase in the nominal interest rate, derived from the model of the Monetary Department, ${ }^{19}$ are presented in Figure 10. The interest rate increase has an immediate and large impact on the exchange rate and thus affects inflation rapidly. The impact on the inflation rate continues for four quarters, as does the impact on the output gap. Relative to other

\footnotetext{
${ }^{18}$ A key question here is how changes in the policy interest rate affect real long-term rates. Hedva Ber, Adi Brender and Sigal Ribon, in "Are Fiscal and Monetary Policies Reflected in Real Yields?", Israel Economic Review, 2, 2 (2004), 15-44, show that monetary policy changes appear to affect the long-term real interest rate (on indexed bonds).

${ }^{19}$ The Bank currently uses two econometric models in making its policy decisions. The Monetary Department model is a New-Keynesian DSGE model for a small open economy. It consists of three structural equations - for inflation, the output gap, and the nominal exchange rate - and is closed with an interest rate rule. The model's structure is similar to others of this type used in a number of inflation targeting central banks, and by the IMF. A key empirical feature of the model is the relative importance of forward-looking elements.

The Research Department model is an augmented version of a textbook quarterly model of a small open economy. It comprises an IS equation for the output gap, a (rate of change) real exchange rate equation, a mark-up equation for inflation, and a business-sector nominal wage adjustment equation. The augmented version of the model includes an endogenous interest rate setting equation for the central bank, but it is possible to use this model also to study the impact of an exogenous path for the interest rate. In addition, separately, the Research Department uses two statistical models to project future inflation rates.
} 
economies, these impacts are quite rapid - a feature that probably on average simplifies the operation of monetary policy when its task is to react to a particular disturbance.

\section{The role of inflation and interest rate expectations in policy decisions.}

Until recently, the Bank attached great weight to inflation expectations in making its policy decisions. This practice was criticized by the IMF as involving a potentially dangerous circularity in which market participants believe the central bank will produce a particular inflation rate and the central bank responds to that expectation - which may not be well-based - rather than basing its actions on a model that ties the impact of monetary policy to its transmission mechanism.

There are at least two answers to this concern. One is that we should regard the expectations of market participants as being based on an explicit or implicit econometric model of their own. Thus the expectations of these market players are not arbitrary, but can rather be considered as being the result of model-based analysis of the factors affecting inflation. Accordingly, in using market expectations as a guide to the behavior of future inflation rates, policymakers are in effect drawing on many models of the economy.

The second - related - answer is that the data tell us not only the inflation expectations of market participants, but also their expectations for monetary policy, as expressed in future interest rates deduced from the term structure of interest. In this regard at least, the market provides evidence that the market participants are using elements of a model of the determination of inflation. In the past year, market expectations of future interest rates have in general been close to my own evaluations of what the Bank was likely to do.

An interesting question that arises is whether or under what circumstances a monetary policy that reacts only to the expected inflation rate would be efficient. The expected inflation rate is one term in the Taylor rule, but the Taylor rule includes a second term, 
the feedback on economic activity. We can assume that omitting this term reduces the effectiveness of monetary policy. ${ }^{20}$ However, if data about real activity is highly inaccurate, then the feedback term on real activity would be low, producing a monetary policy that reacts mainly to the expected inflation rate.

Nonetheless, I do accept the IMF criticism that the central bank should also use its own models and form its own expectations in making interest rate decisions, lest its decisions be too much dependent on the (possibly wrong) expectations of the markets. We have thus been trying to develop our econometric models and to use them more consistently in making our policy decisions. In addition, the Bank has recently given greater weight than before to estimates of the output gap in making its interest rate decisions.

\section{What inflation rate is being targeted?}

I want to discuss two issues under this heading. First, as previously noted, the monthly Israeli inflation rate is more variable than inflation in the advanced economies. ${ }^{21}$ This variability makes it harder to hit the inflation target within a period of, say, a year. Consideration has therefore been given to targeting some measure of core inflation. However targeting core inflation would make the inflation-targeting approach of monetary policy less transparent and more confusing, since there is not an obvious definition, nor decisive empirical evidence, regarding which components of inflation should be in the core.

At present headline inflation according to the CPI is broadly accepted as the appropriate measure of inflation. The more the central bank would target a concept of inflation other than the measure with which consumers are familiar, and which appears most relevant to their experience, the greater the risk of a loss of confidence and credibility in monetary policy. Further, sustained periods during which headline inflation exceeded core

\footnotetext{
${ }^{20}$ This proposition can be examined using any standard econometric model.

${ }^{21}$ As my colleague, Karnit Flug, has argued, the greater uncertainty about future inflation rates could imply that the Israeli inflation band should be wider than that for other countries where there is less variability in monthly (seasonally-adjusted) inflation. This possibility should be borne in mind, but there seems no good reason to increase the width of the target band at present.
} 
inflation - as has happened for instance in the United States during the last three years could lead to a further loss of credibility for the inflation-targeting regime. Thus the Bank of Israel will continue to target headline CPI inflation.

Second is the question of the horizon over which inflation is targeted. Because the inflation rate is quite variable and hard to predict over long periods, we generally use a twelve-month horizon in discussing future inflation. We also report on inflation rates over the past twelve months, and take them into account in making the interest rate decision. If we were to refer only to expected inflation, we could find ourselves in a situation in which we would be always on target in terms of expected inflation over the next twelve months, while not being within the range over long periods - an outcome which we believe could lead to a loss of credibility. ${ }^{22}$ Such a situation obtained for instance during 2003-2004 when actual inflation was below the target range while expected inflation was well within the range (Figure 2 ). ${ }^{23}$

It might be asked why, if the inflation rate is hard to predict, expectations of inflation are stable. The answer must be that the expectations are based on the assumption that the central bank will pursue an active monetary policy that will on average keep the inflation rate around the center of the target range.

\section{Interest rate gap with the US}

As can be seen in Figure 8, there has been a high correlation between the Fed's policy rate and that of the Bank of Israel since October 2005. Market participants and journalists have raised the question of whether the Bank has a policy of maintaining a fixed spread over the Fed's rate. The answer is no. In fact, within the past year, the spread has at some points been negative, zero, 25 , and 50 basis points respectively.

\footnotetext{
${ }^{22}$ See Lars Svensson and Michael Woodford (2005). "Implementing optimal policy through inflation-forecast targeting", Chapter 2 in Bernanke and Woodford (eds), The Inflation-Targeting Debate. NBER, University of Chicago Press.

${ }^{23}$ The point here is that we believe we are more likely to stay within the range if we look back as well as forward - not that there is a problem in having expected inflation over the next 12 months be within the range even when the actual inflation rate for the past 12 months was outside the range.
} 
Nonetheless, the interest rate spread with the U.S. does affect capital movements, thus the exchange rate, and thus the inflation rate. Accordingly we do take the spread into account in making the interest rate decision - as one factor that affects the inflation rate, which is the variable we target. Ceteris paribus that means that we are more likely to raise the Bank of Israel interest rate if the Fed's rate rises than if it does not change. But there is no policy of relating to the interest rate gap other than because it influences the inflation rate. If, for instance, the relative degree of confidence in the Israeli and United States economies were to change, the exchange rate would be affected, and because that would likely affect inflation, the Bank of Israel policy rate would also be likely to change relative to that of the Fed

\section{Monetary independence in a world of inflation targeters.}

The textbooks tell us that a country with a floating exchange rate has monetary independence that is denied to a country that pegs its exchange rate - because the country with the peg has to accommodate its interest rate to foreign interest rates. However, as the discussion above shows, an inflation targeting country with a floating exchange rate nonetheless has to take movements in foreign interest rates into account in setting its exchange rate.

Does this mean that the combination of floating and inflation-targeting implies a loss of monetary independence? Actually, the loss of monetary independence comes when the country specifies its inflation target, for that target determines the required interest rate. It remains true that the floating rate gives the country more policy independence, by allowing the exchange rate to adjust to domestic or foreign disturbances in a way that would be impossible if the exchange rate were pegged.

Accordingly we should amend the standard textbook statement to say that by choosing a flexible, rather than pegged, exchange rate, a country gains monetary independence, which it may use for instance to pursue an inflation targeting regime. In addition, by 
allowing the exchange rate to float, rather than pegging it, a country gives itself the capacity to allow the exchange rate, in addition to domestic wages and prices, to take the burden of adjusting to shocks.

\section{Transparency, Openness, and Communications}

During the last year we have tried to increase the transparency of our monetary policy decisions, first by becoming more specific on the reasons for our monthly interest rate decisions in the announcement of the decision, and second, more recently, by beginning to publish a more detailed set of minutes on the meetings in which the decision was reached.

We faced the choice of whether to publish a more-or-less blow-by-blow account of the discussion, or whether to try to organize the points raised in the discussion into a more coherent form - this is broadly the difference between the minutes published by the Fed and the Bank of England respectively. In considering the choice we were influenced by the concern that the publication of the minutes not mislead the markets, as for instance happened in January 2006 when we published the half-yearly Inflation Report, which stated that we expected the interest rate to rise during the course of the year. This was taken by the markets as an indication that the rate would rise at the next meeting, which was not our intent. Accordingly, we opted for the Bank of England approach, which attempts to organize the discussion into a reasonably coherent form. No doubt there will be occasions on which the publication of the minutes will not clarify the situation sometimes because the situation is unclear, sometimes unfortunately because we do not choose our words well enough.

There are also some limits on transparency. In particular, people within the central bank, or any decision-making body, have to feel free in their discussions to raise their concerns, to discuss hypothetical situations, and even to make mistakes as they consider alternative courses of action. Total transparency of all discussions would inhibit those discussions and limit the range of issues considered, and there thus need to be limits on what is 
published. ${ }^{24}$ And decision-making bodies need also to take account of the potential impact of leaks - for instance, in a central bank, leaks of market-sensitive information. For this reason a central bank cannot countenance a culture of leaks.

In a democracy, the more open the central bank can be without impairing its effectiveness, the better - a central bank that is both open and successful is likely to be more credible in its pronouncements. Transparency can thus be regarded as a multiplier, which makes success more successful, and punishes failure more rapidly; it thus also provides important incentives for better performance.

\section{Non-Monetary Policy Issues}

In addition to the monetary policy issues are several issues associated with other aspects of the job.

\section{Economic Adviser to the Government}

The Bank of Israel law of 1954 describes the Governor as the chief economic adviser to the Government. In the past there has often been public controversy between the Bank and the Treasury. Treasury-central bank tensions occur from time to time in other countries, and they are understandable given that together these two institutions bear responsibility for overall macroeconomic policy. But in Israel those tensions exacerbated by the vigor of public debate - have sometimes reached impressive levels.

Although Governors in advanced countries may comment on policy, particularly fiscal policy, the Governor is not usually formally designated as economic advisor to the government in these countries. That role is less rare for governors of emerging market and developing countries. In Israel the role probably derives from two main sources: the strength of the Research Department of the Bank of Israel as the primary applied

\footnotetext{
${ }^{24}$ These limits are time-sensitive, and in most cases material that cannot be published contemporaneously is published later.
} 
economic research institution in the country; and the need for a balance to the strength of the Treasury in economic policy-making.

The role of an adviser is a difficult one, and I do not believe that an adviser is likely to be successful if he or she focuses on providing advice in public, via the media. Accordingly I have chosen generally to give advice to the government by first speaking to the relevant decision-makers in the government, and by focusing public comments on a few key issues, including the importance of maintaining a strong fiscal framework and reducing the debt-GDP ratio in Israel, poverty, the importance of continuing structural reforms, and support for globalization. On occasion, when my advice is not accepted, I will speak out in public.

This strategy has led some in the press to express the concern that the public is not being properly informed on the issues. The test of whether the current approach is appropriate will only be seen over the course of time. Of course, this approach is more appropriate when the governor views the overall approach of the government to economic policy as being broadly correct.

\section{Banking Supervision}

The Supervisor of Banks reports to the Governor, and I have thus during the last year had my first supply-side experience of bank supervision. Bank supervision demands a host of talents that are not related to the ability to conduct monetary policy. In particular, I have found the "fit and proper" examinations interesting but difficult, since the judgments end up having to be based on incomplete information. And because modern banking is a complex business, the general approach to supervision is due to change as Basel II is being introduced globally - and slowly - among more advanced banks. The advanced approach of Basel II accepts that the supervisor should supervise the risk management systems of the banks, rather than try to impose detailed risk weighting schemes of the supervisory bodies. This will demand different and more sophisticated skills from 
supervisors, and significantly complicate their task. Around the world it looks as if the advanced approach of Basel II will first be implemented between 2008 and 2010.

The trend at present is to remove bank supervision from the central bank and to concentrate financial supervision in a single agency, of which the UK's Financial Services Authority is the best known. This should also help set uniform standards for a variety of financial institutions that do similar things, but have different names. In the Israeli case, the Bachar Committee recommended reconsideration of the structure of supervision in the years following the implementation of its reforms to divest the banks of the various funds that they controlled. As those reforms have been implemented, the need for greater uniformity of supervision has become ever clearer as insurance companies and pension funds move into the provision of credit to firms.

In the debate over unified supervision outside the central bank, versus retention of the bank supervisory function in the central bank, central banks generally stress the need of the central bank, as lender of last resort, to know the state of individual banks and the banking system (and financial system more generally) extremely well, and argue that that is best done by keeping supervision within the central bank. Whatever the final structure of financial supervision in Israel, it is important that the supervision of insurance companies and mutual and providential funds be given greater independence.

It is also essential that there be greater coherence and cooperation among the regulators. To that end, the four main regulatory authorities in Israel - banking supervision, insurance and investment fund supervision, the capital markets authority, and the competition authority - are currently working on an MOU that will define their modes of cooperation.

The supervisory issues are critical to the stability of the macroeconomy. They need to be taken up and analyzed carefully, with the goal of maximizing the efficiency of financial sector regulation. This involves not only the stability of the financial system, but also its efficiency and ongoing modernization. 


\section{Reflections on the Israeli economy}

I have been impressed during the last year by the performance of the Israeli economy, as much by its resilience as by the rapid growth combined with low inflation. The resilience has been demonstrated by the stability of the financial markets and of the exchange rate during the past year despite a series of major disturbances - the resignation in August 2005 of Finance Minister Netanyahu, who was seen as the architect of the economic policy that contributed importantly to leading Israel out of the recession of 2001-2003; the illness in January 2006 of Prime Minister Sharon and its consequences; the election in the same month of Hamas; and the Israeli elections in March 2006.

This resilience must derive in large part from confidence in the overall economic framework, which accepts globalization and ongoing integration into the global economy as key to growth for a small economy. On the macro side policy combines a responsible fiscal framework with an inflation targeting approach to monetary policy; and on the micro side the framework accepts - on the whole - market-friendly policies.

But there are major forces pushing in other directions. These derive especially from the coalition structure of Israeli governments, where the essential question is which parties get which ministries. The spending ministries as everywhere have a tendency to measure success by the size of their budget, but in the Israeli case they are not bound by party discipline. This is why the Treasury has over the years built up a formidable framework of control over spending, which other ministries regard as excessive.

In addition, poverty in Israel has been worsening for the last five years, and this leads to pressures to increase welfare spending. Some of these pressures are justified. But not all of them. And the political tendency to think only of expenditures that should be increased, and not about changing priorities, poses a continuing challenge to maintenance of fiscal discipline. 
In reflecting on the economy, I have been struck by the importance of the opening of the capital account of the balance of payments that took place during the nineties and the first part of this decade. I used to think of capital account liberalization as a technical issue. Now I see it as far more important than that, for the opening of the capital account in both directions has changed the world view of most participants in the economy. Israeli corporations and consumers used to think locally, now they think globally. Their markets are global, their sources of finance are global, their sources of knowledge are global - though in this last respect, Israel has always understood the need to think globally. This change has been almost entirely for the better. ${ }^{25}$

\section{Reflections on Running a Central Bank}

Before taking the job, I thought that the main task of the Governor was to direct monetary policy and the other policy missions of the central bank, namely bank supervision and the provision of economic advice to the government. I still think that.

However in practice most of my time during the first year on the job has been devoted to other issues: notably to settling a particularly long-lasting wage dispute with both the workers' union and the Treasury; to reorganizing the Bank; to working on the passage of a new law for the Bank of Israel; and to dealing with media issues, many of which are the negative inheritance of past labor and other disputes.

But I was also fortunate to inherit a central bank with a highly professional and experienced staff in key areas of the bank's responsibility. The institutional arrangements for reaching the monthly interest rate decision work well, as does the staff involved in the process. Early in my term I learned from them one of the key lessons of policymaking, when I said that we could wait another month to change the interest rate because the situation would then be much clearer. Deputy Governor Meir Sokoler said: "It's never much clearer a month later" - and he could have added, "it's just unclear in a

\footnotetext{
${ }^{25}$ But not entirely, for Israel also has a large number of imported workers, an issue that creates serious policy issues.
} 
different way". That view is not entirely true, for it is sometimes correct to wait, but it is a good warning about the dangers of falling behind the curve.

I have also learned the benefits of being a member of the international financial institutions, especially the IMF and the BIS - and soon, I hope, the OECD. They are where the lessons of international experience reside and can be learned, and where international standards are developed and maintained. And that is immensely helpful for a small economy, aspiring to strengthen its institutions and policies. For instance, we in the Bank of Israel have benefited greatly from the visit of a top-rate IMF mission that reviewed the banking supervision system in Israel, and from constant interaction with the BIS and colleagues in other central banks in developing and refining the new law of the Bank of Israel.

And of course, I was also lucky to take office at a time when the economy was expanding rapidly, with the recovery well established, with low inflation, a current account surplus, and a stable currency. If you plan on becoming a Governor, try to start that way. 


\section{Figure 1: Quarterly Growth Rates (in annual terms)}

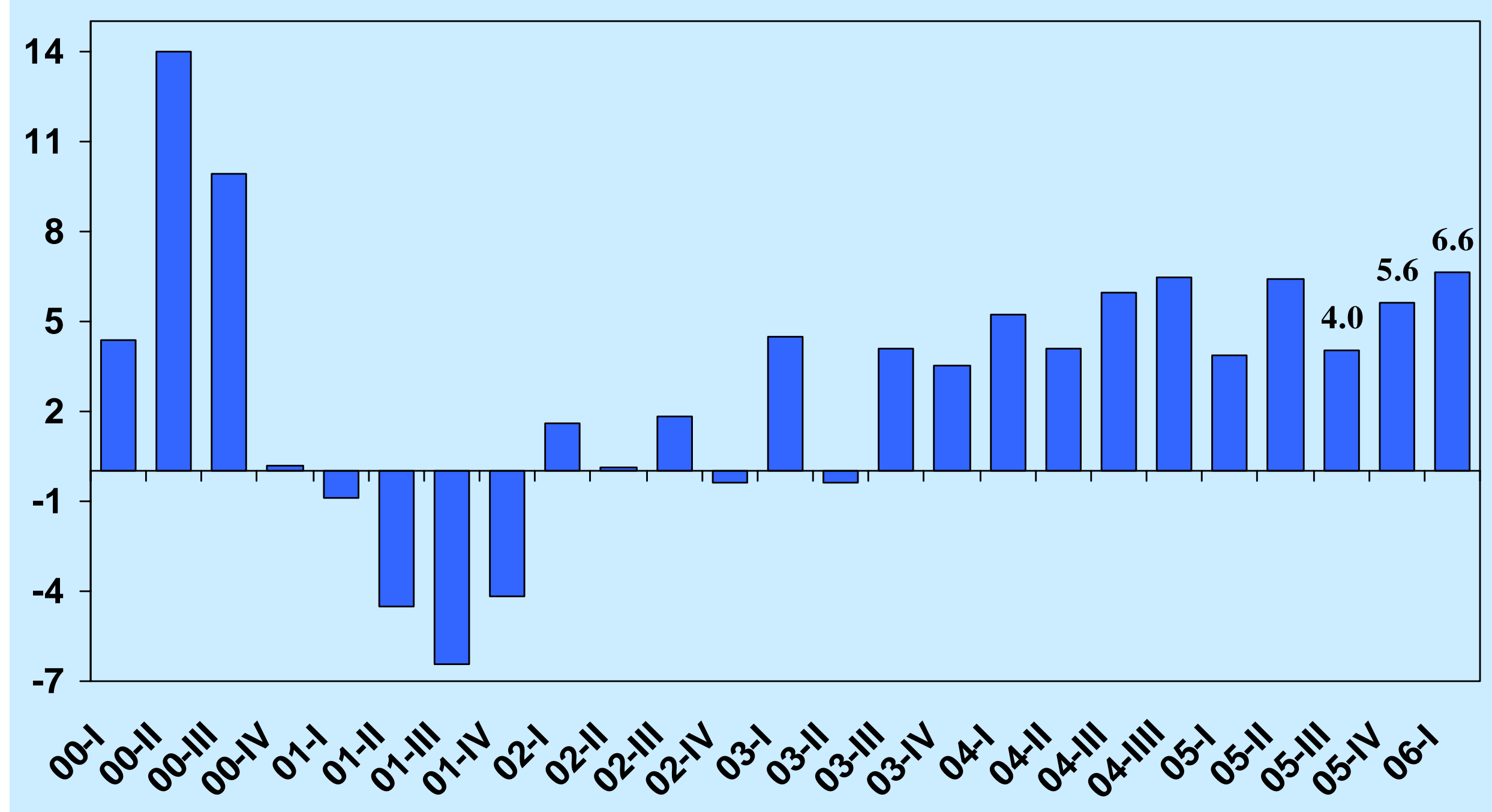




\section{Figure 2: Inflation During the Last 12 Months and the Inflation Targets}

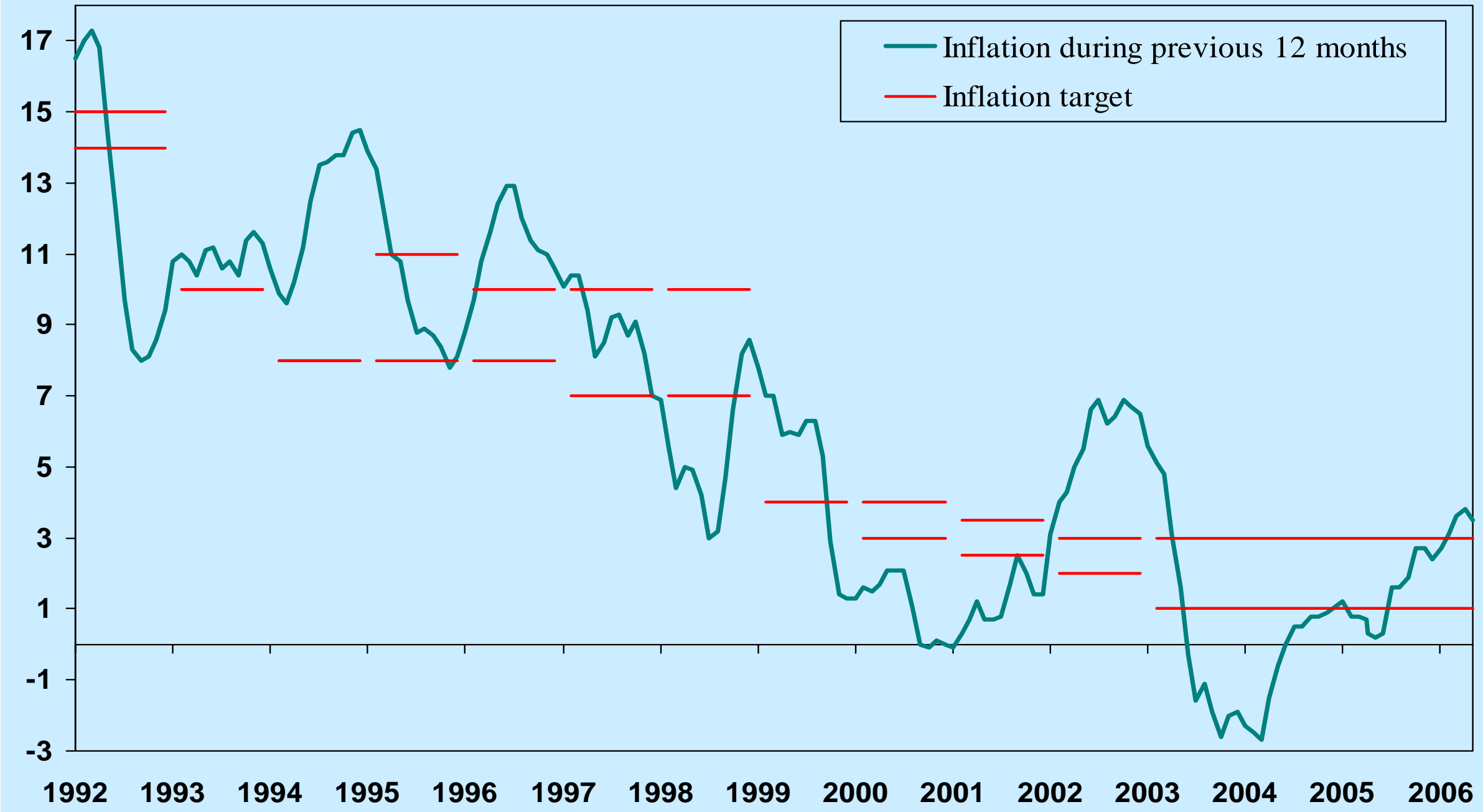




\section{Figure 3: NIS/Currency-Basket Exchange Rate}

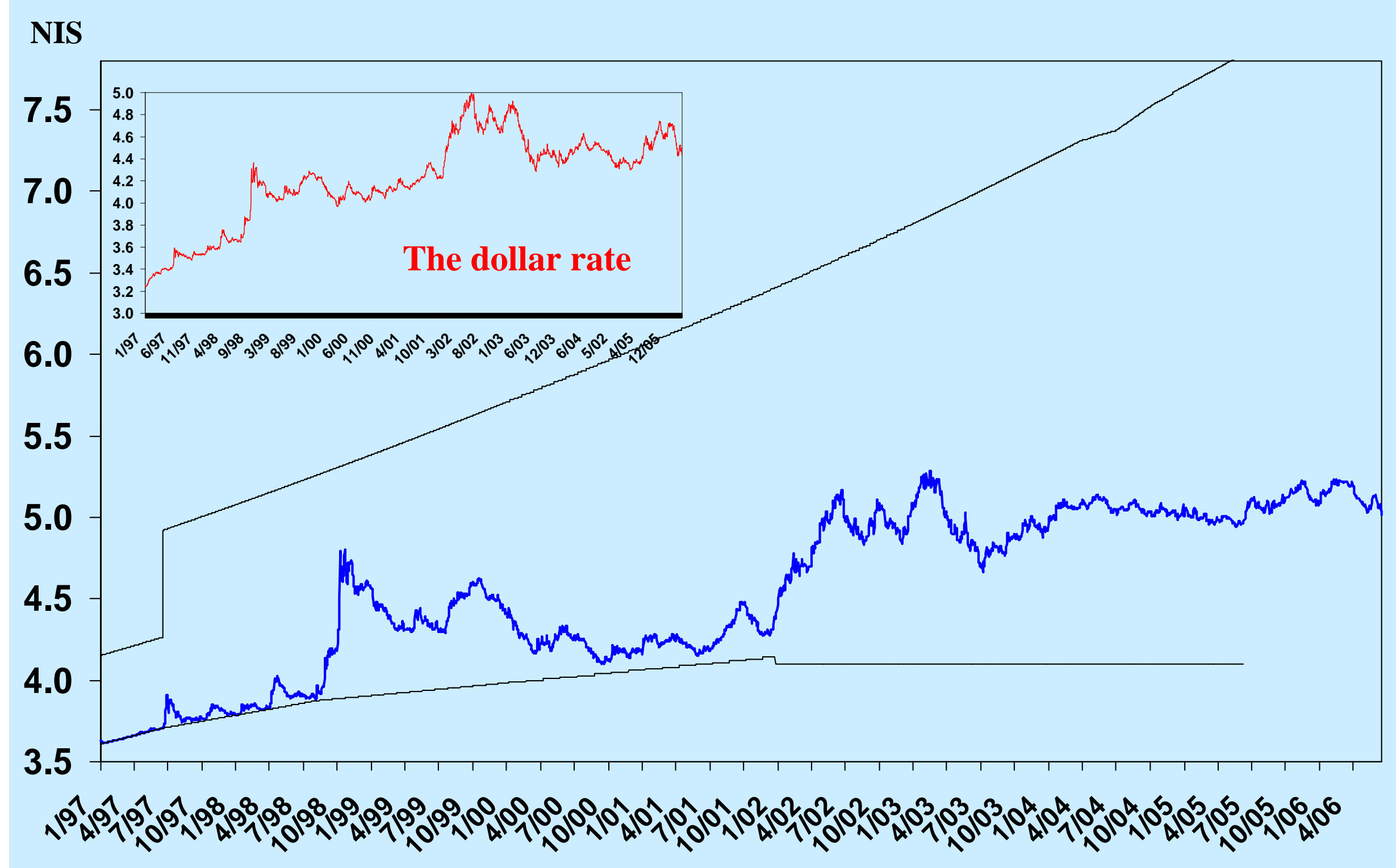




\section{Figure 4: Openness of the Israeli Economy}

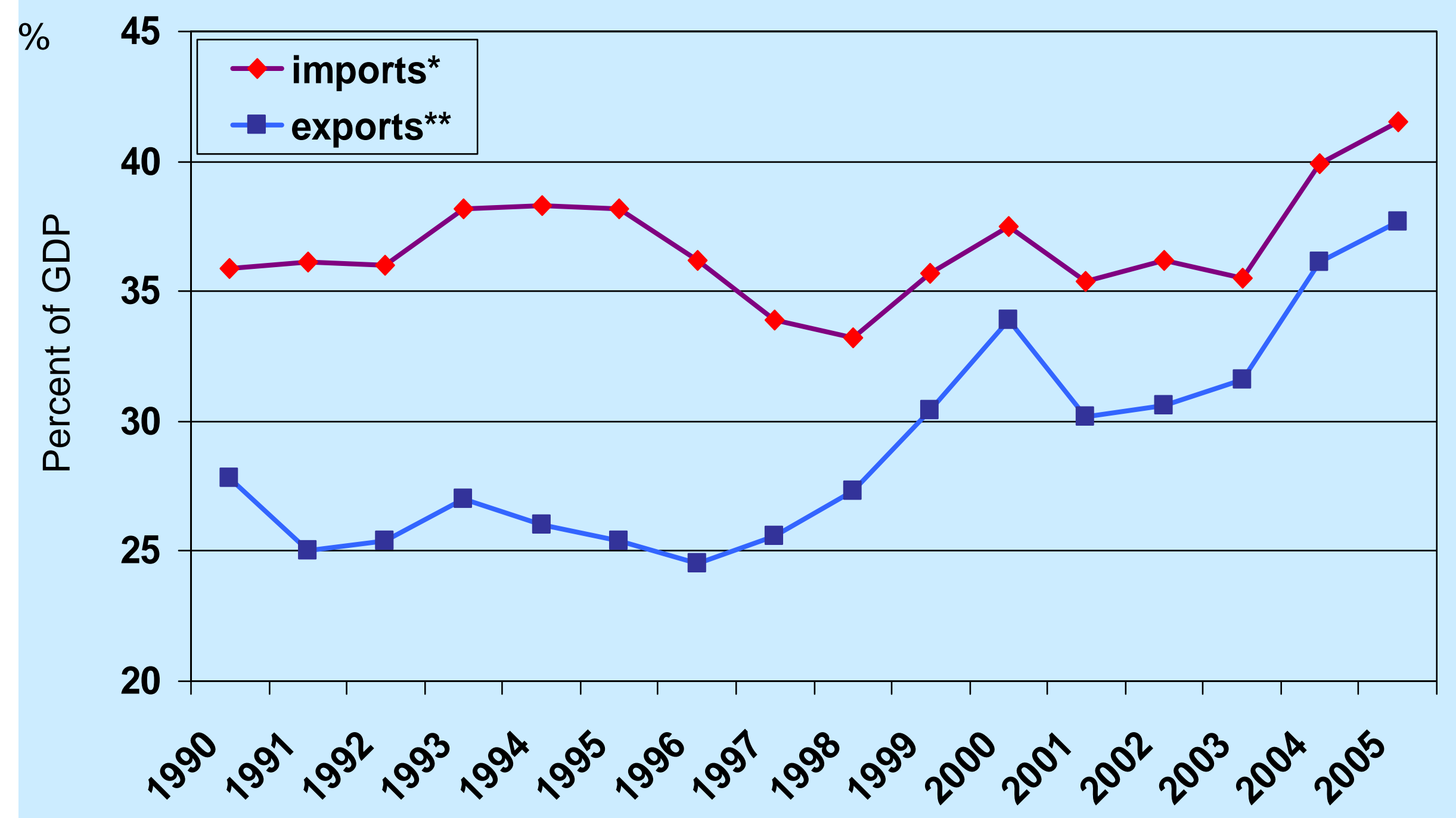

${ }^{\star}$ Excluding diamonds, ships \& aircraft ${ }^{\bullet}$

**Excluding diamonds• 


\section{Figure 5: Foreign Investment in the Israeli}

\section{As Percent of GDP}

\section{Economy}
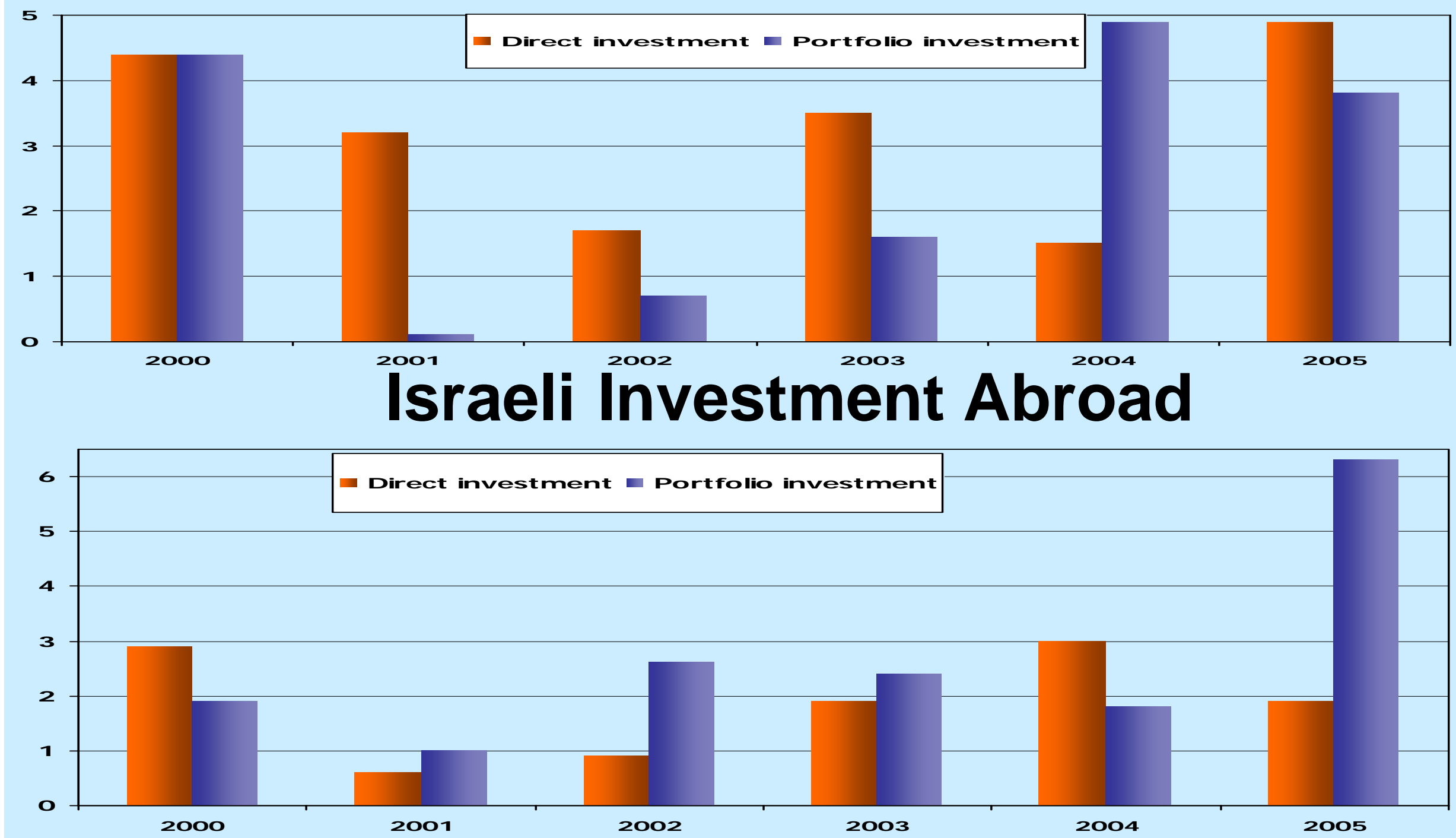

Source: cbs 


\section{Figure 6: The deficit of the general government 1990-2005 (\% of GDP)}

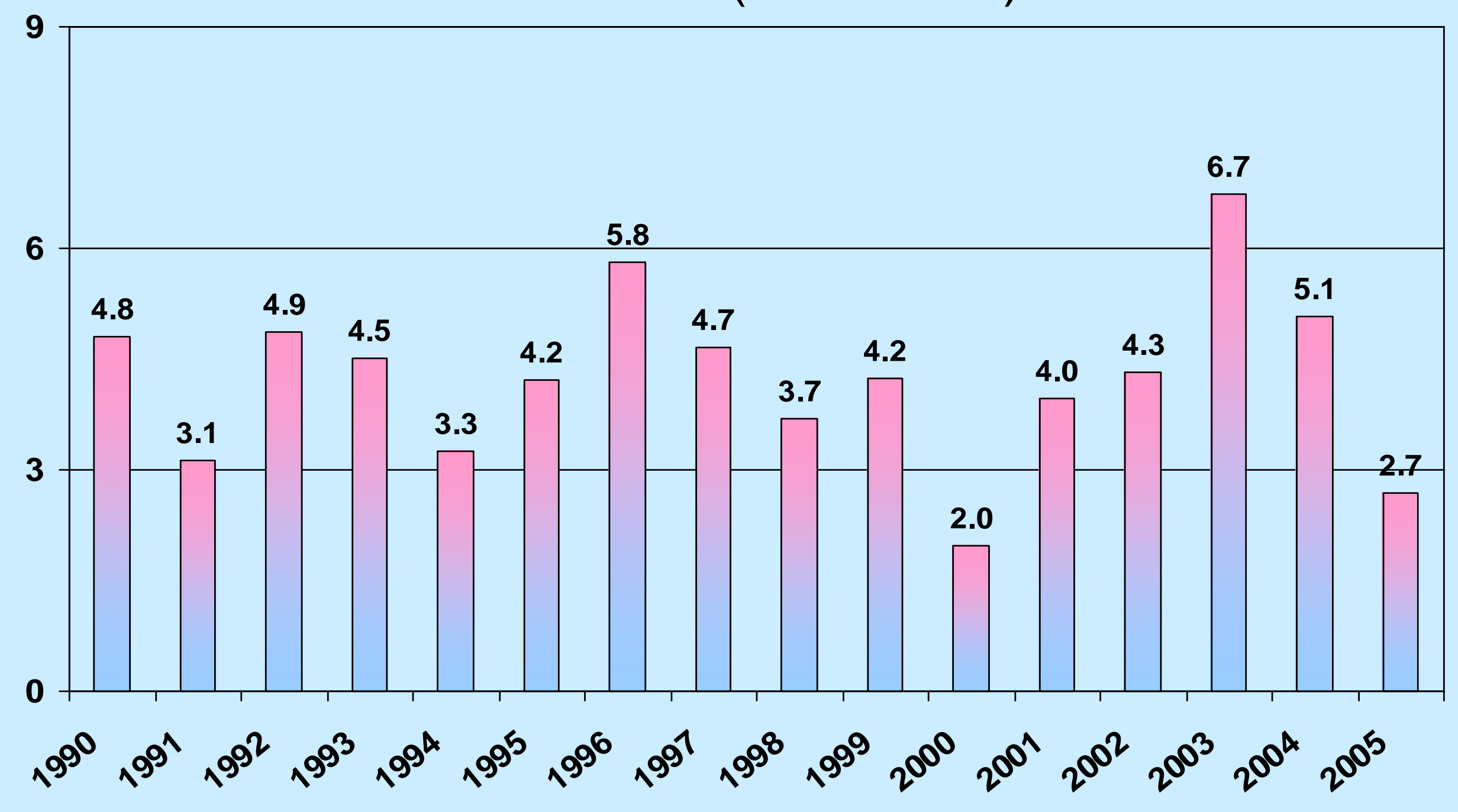


Figure 7: Unemployment Rate

$\%$

1997-2005

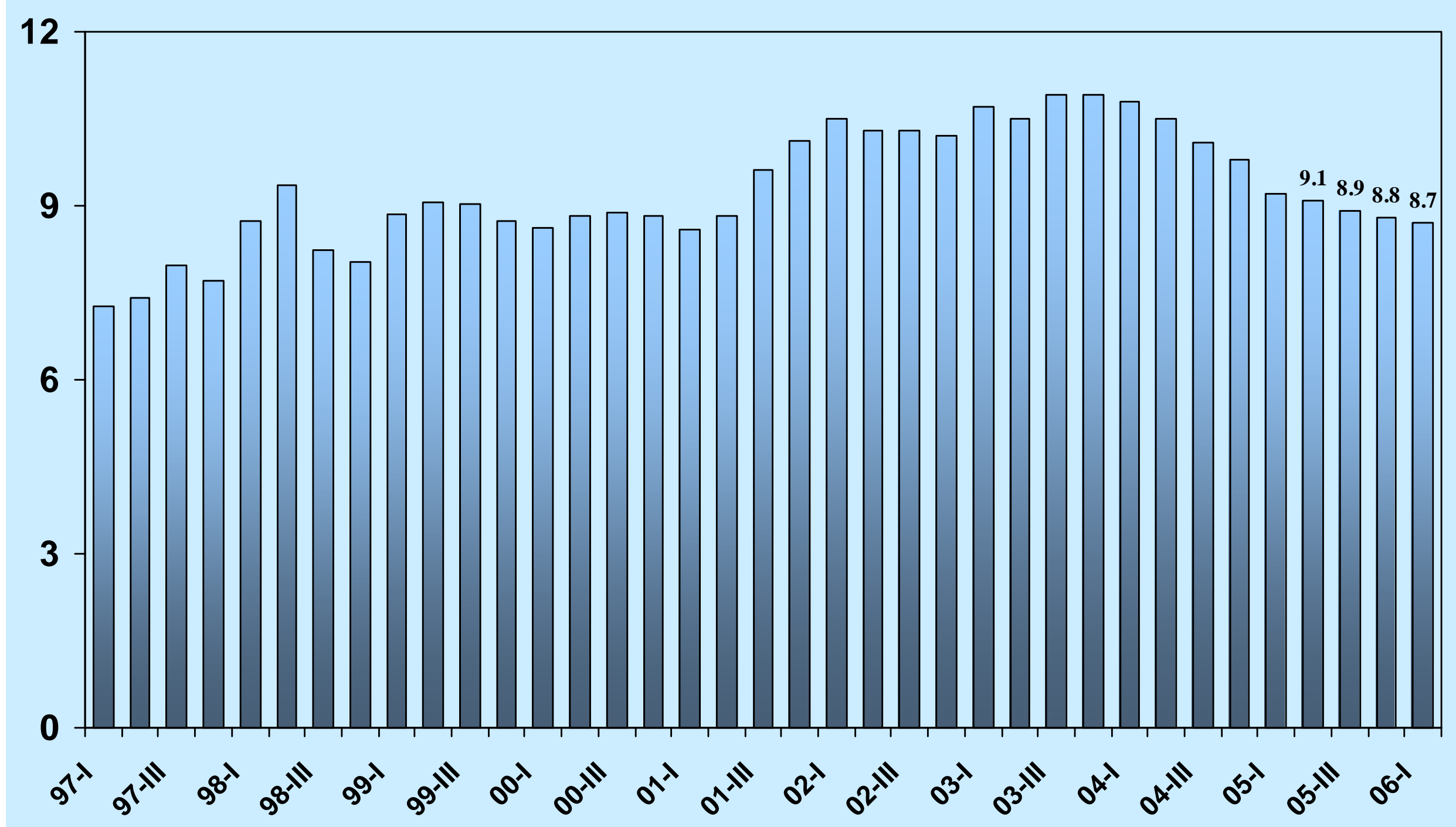

SOURCE: Based on Central Bureau of Statistics Labour Force Survey. 


\section{Figure 8: Poverty Rate, Alternate Definitions}

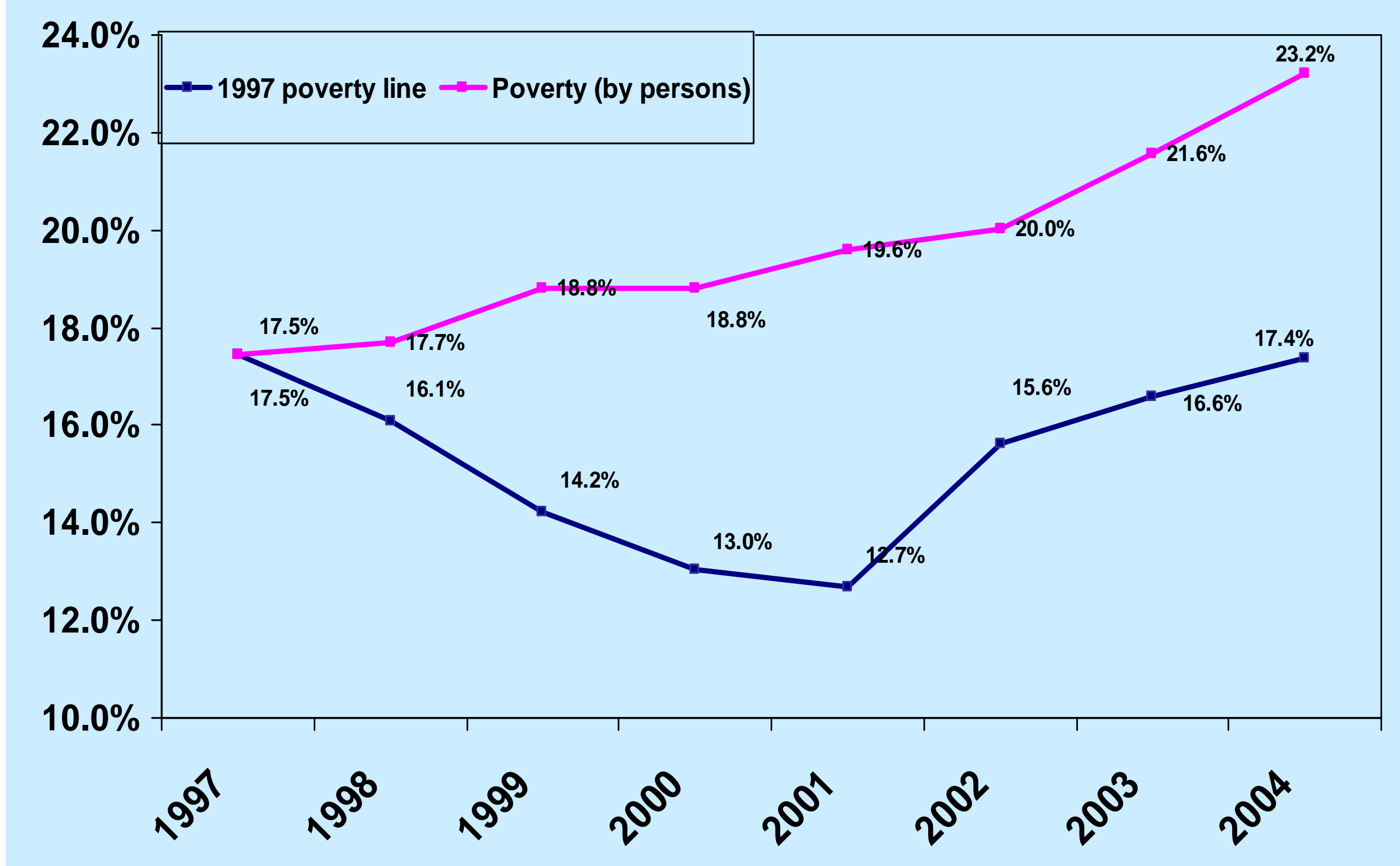

*SOURCE: Central Bureau of Statistics Income and Expenditure Surveys. 


\section{Figure 9: Bank of Israel Interest Rate, Inflation Expectations*, and}

$\%$ the Fed's Interest Rate, 2004-2006

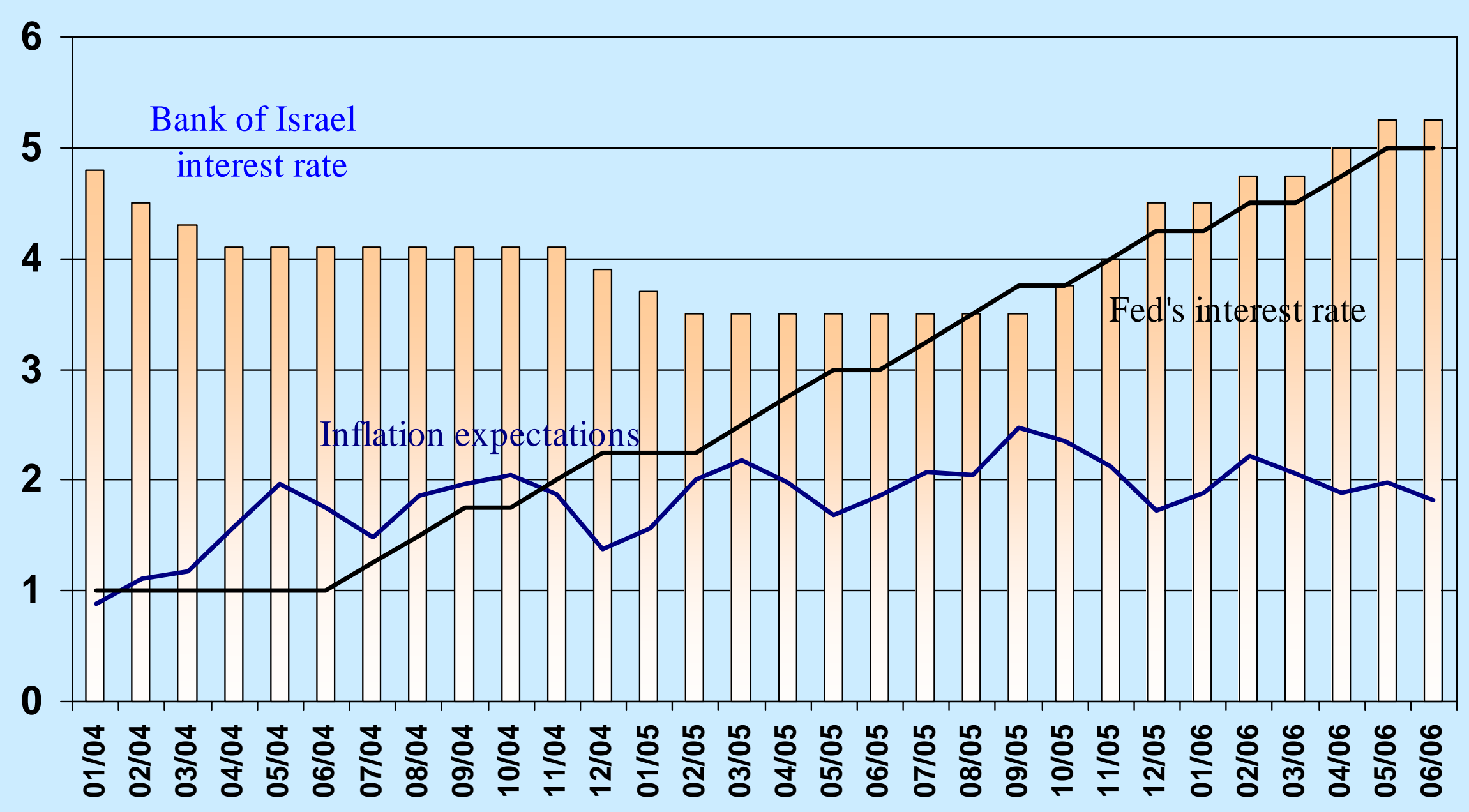

*For 12 months, as derived from the capital market. 


\section{Figure 10: Response to a 100 Basis Point Increase in the Bank of Israel's Interest Rate (Deviation from baseline)}
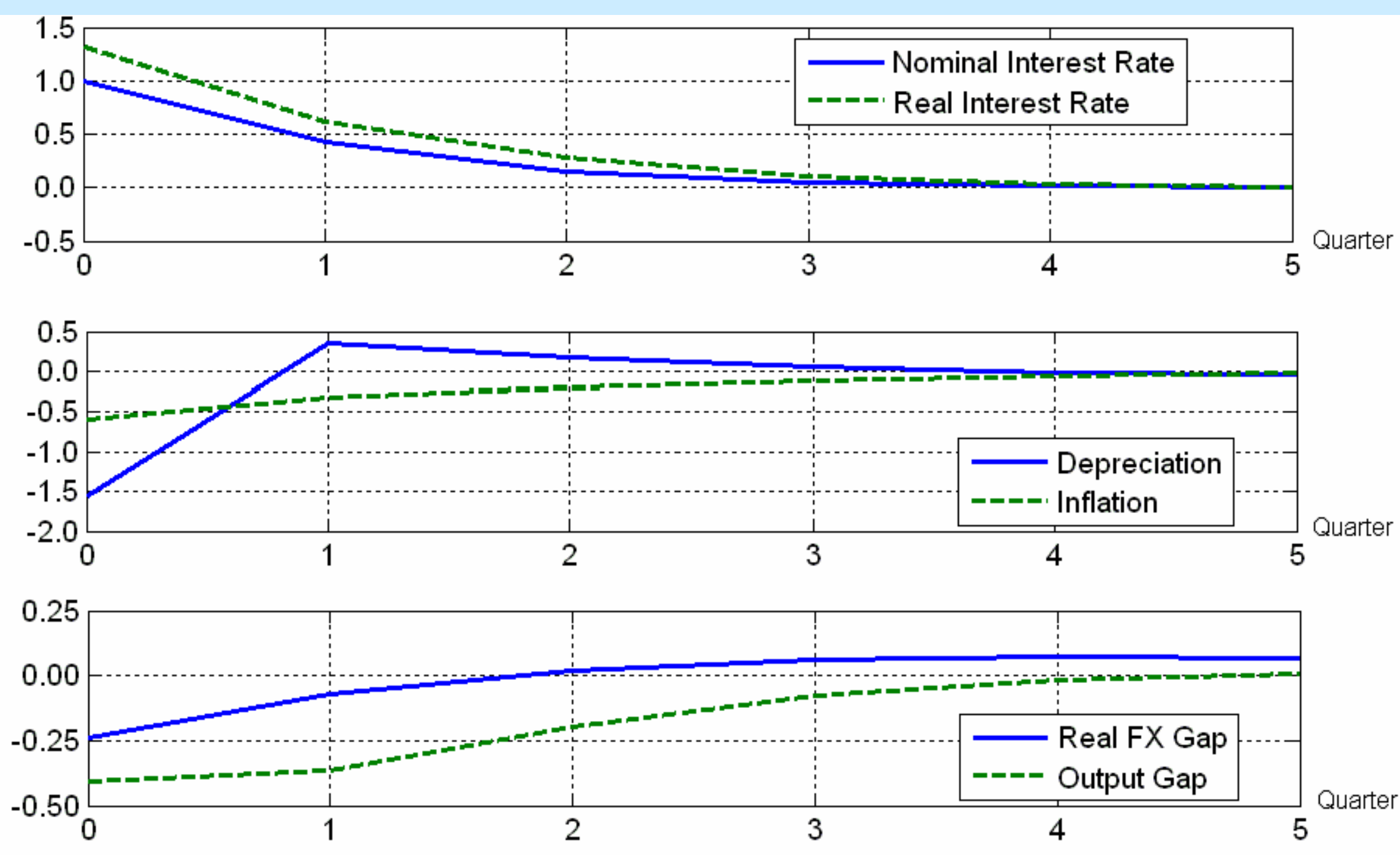